\title{
Credit Management in Full-Fledged Islamic Bank and Islamic Banking Window: Towards Achieving Maqasid Al-Shariah
}

\author{
Najihah Muhammad ${ }^{1}$, Sharifah Faigah Syed Alwi ${ }^{1} \&$ Nabihah Muhammad ${ }^{1}$ \\ ${ }^{1}$ Arshad Ayub Graduate Business School, Universiti Teknologi MARA, Shah Alam, Malaysia \\ Correspondence: Najihah Muhammad, Arshad Ayub Graduate Business School, Universiti Teknologi MARA, 40450 \\ Shah Alam, Selangor Darul Ehsan, Malaysia. E-mail: najihah0405@gmail.com
}

Received: March 16, 2020

Accepted: April 30, 2020

Online Published: June 29, 2020

doi:10.5430/ijfr.v11n3p92

URL: https://doi.org/10.5430/ijfr.v11n3p92

\begin{abstract}
The percentage of non-performing loans (NPL) and non-performance financing (NPF) in Malaysia commercial banks is under control and does not increase in its percentage since the year 2014 to 2016. These scenarios are the result of the stringent credit management procedures in the commercial banks which if not properly followed could affect banks' profitability and liquidity. However, there are critics by the public on how Islamic banks normally tend to punish their customers who are the real traders or businessman without fixed monthly income when they slightly late in paying their periodical payment for the bank's facility or financing. Islamic bank is supposed to help the customer in order for it to achieve maqasid al-Shariah (objectives of Shariah). Thus, this study intends to compare the credit management's procedure in one of the full-fledged Islamic banks and one of the conventional banks which also offer Islamic banking window. This study also aims to identify the achievement of maqasid al-Shariah through the procedures of credit management in the two banks. This study adopted the qualitative methodology where semi-structured interviews are conducted with 2 bankers from one of the full-fledged Islamic banks and one of the conventional banks which also offer Islamic banking window. Results from this study indicated that each banks has their own strategies and procedures with regard to credit management. Their credit management plans were structured to help customers to secure their loans, financing and assets as well as protecting them from bankruptcy and insolvency which basically comply with maqasid al-Shariah. From this study, it is recommended for commercial banks to apply a strict approval process for loan and financing as well as a strict credit monitoring system to avoid NPL and NPF.
\end{abstract}

Keywords: credit management, full-fledged Islamic bank, Islamic banking window, Maqasid al-Shariah

\section{Introduction}

According to Abdullah and Abd Wahab (2015), the Islamic banking system has emerged as a competitor and a feasible substitute for the conventional banking system during the last three decades. It is evidently true in the Muslim world where presently Islamic banking is operating in two separate fronts. On one side, efforts are underway to switch the entire banking system to be in accordance with the Islamic laws. On the other side, separate Islamic banking is permissible to operate in parallel to conventional interest-based banks.

Loan is the main product offered by both conventional bank whereas financing is the core business of Islamic bank. However, as every loan or financing cannot be separated from default risk, there is always a probability of the bank facing the default and delay from the customer during the repayment period. Therefore, there is a possibility of non-performing loans (NPL) and non-performing financing (NPF) to incur. Karim, Chan and Hassan (2010), stated that if a bank's asset are inadequate, the bank needs to increase its bad debt losses as well as spend more resources on the collection of Non-Performing Loans. Eventually, the management of NPL/NPF needs an insight to ensure the stability of the banks and the soundness of the financial system. In order to ensure the stability of Islamic banks, the financing facility which contribute a large amount on part of the banks' liability, needs to be managed efficiently and systematically. If that happens, it can lead to the reduction of the number of NPL and NPF which will affect the banks' liquidity.

Statistics from the World Bank (2017) show that in the year 1999 to year 2015, the bank's NPL to total gross loans decreased from $16.6 \%$ to $1.6 \%$. An increase in NPL will affect the bank's profitability and liquidity that are the key mechanism for the efficiency of the bank. An increase problem in loans also will direct to negative impacts on bank 
efficiencies. Dimitrios, Helen and Mark (2016) state that bank's insolvency has been a significant problem in many countries all over the world. It is argued that it will have an unfavourable effect since such banks will apply additional managerial effort and give additional expense dealing with these loans (Karim, Chan \& Hasan, 2010).

Islam upholds an economic vision, which is the key to a social order capability, in order to provide social justice along with economic prosperity. This vision is deeply inscribed in the objectives of Shariah, also known as maqasid al-Shariah (objective of Shariah) (Abozaid \& Dusuki, 2007). Hence, the efforts towards the basic development of Islamic economic which contain the elements of maqasid al-Shariah are needed and cannot be forgotten. Ibn 'Ashur said that "forgetting the elements of maqasid in Shariah is the factor that leads to the failure of achieving objectives of fiqh". The elements of maqasid in Shariah here mean protection of faith, life, wealth, intellect and lineage of human beings. However, in the case related to Islamic banking and finance, the protection of wealth is more obvious and significant.

Lahsasna (2013) states that Islam gave a great concern regarding the wealth and property. The objectives of Shariah in wealth are revolving around the preservation of wealth and property. Property is the mainstay of life, and Islam considers it as Allah's (S.W.T), which Allah makes man a guardian over it, and allows him/her to earn them in lawful ways and use them moderately. Islam also encourages work, production, and earning money and other property by lawful means. In surah Al-Mulk, verse 15,

"It is He Who has made the earth manageable for you, so traverse you through its tracts and enjoy of the Sustenance, which He furnishes: but unto Him is the Resurrection."

According to Abadi (2008), maqasid is Arabic word which means goal, intention or purpose. However, when it refers to Shariah (maqasid al-Shariah), it is exclusively meaning the goals and purposes of Shariah. Shariah looks for the welfare of the people in this life and in the hereafter, and for this reason, it recommended the people to implement such means and measures that may give benefit to their well-being and at the same time may protect against evil, injury and loss from happening. Islam has a very clear viewpoint on debt as it is urged from the Qur'an and several hadiths from the Prophet Muhammad peace be upon him (p.b.u.h). Firstly, it is related to the activity of earning a profit from other people's indebtedness. Allah says in the Qur'an:

"O believer! Fear Allah and give up that riba (usury) which is still due to you, if you are true believers." Surah Al-Baqarah, verse 278 .

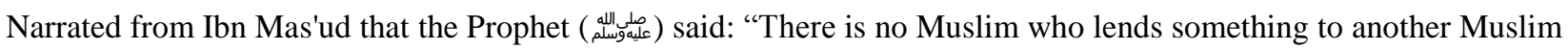
twice, but it will be like giving charity once."

Although the act of giving loan to those in need is encouraged in Islam, the lender should be extra careful as they need to grant it to those that only have the capacity and capability to repay it. Especially in the real banking industry, as the case of indebtedness can be worsened by having bankruptcy or insolvency. Nowadays, with the existence of Islamic bank, which can fulfil the needs of debtor by granting them financing, the element of riba, which is prevalent in conventional banks and is prohibited in Islam, can be avoided.

Classical Muslim jurists have discussed the Shariah principle of insolvency and the general rules on how to deal with the debt liabilities followed by default. A few of these could still be served as the basis for current application of Shariah principles. However, a new revision of this principle and rules are needed due to the changes of nature of the modern business as well as changes in local and international legislations (Kamali \& Yussof, 2013).

Undoubtedly, maqasid al-Shariah refers to the holistic view of Islam, that suggest that is must be looked at as a whole, not in segments. This indicates that Islam is a complete way of life, including its goals to encompass all aspects of life, especially for each individual and society, in this world and more importantly, in the hereafter (Abozaid \& Dusuki, 2007). Hence, pure profit maximization cannot be a major goal for a Muslim society. The want for maximization of profit must be accompanied with an effort to safeguard spiritual health of human consciousness and fair dealings at every level of human interaction. Only this kind of development would conform with maqasid al-Shariah (Chapra, 2016).

The problem of NPL with maqasid al-Shariah, NPL is supposedly be alleviated as it may become a burden for both lender and borrower. The adverse effects of NPL include the breaking of the contract of credit supply, distortion of credit allocation, slowing down the economic growth and worsening market confidence. Through financing, the customer supposedly gains benefit by obtaining asset or enhance their business. Banks on the other hands can help customers and at the same time obtain profit from deposits. 
Islamic banks are supposedly able to realize maqasid al-Shariah through financing given to the customers and at the same time able to help them through good and bad times. However, according to Bakar (2016), numerous Islamic bankers look at the corporate client's behaviour as officers of credit, instead of looking from any business point of view. They cannot even comprehend the dynamics of cash flow, management as well as the complete cycles and ecosystem of the business. To make it worse, they tend to punish real traders when they are slightly late in their periodical payment for facility under a letter of credit working capital or even for overdraft under commodity murabahah (mark up) financing.

Bakar (2016) states that the financiers are allowed based on Shariah point of view to impose late payment charges if the client is behind on their schedule. Nonetheless, they cannot simply mark this client as a 'bad' or 'defaulting' client, which may affect their credit rating. This is because of the nature of corporate business sector, whereby their cash flow cycle is unstable compared to the salaried customers in retail or consumer financing which received fixed wages every month. If this kind of mentality and practices is to be continued, eventually it would bring more disgrace to Islamic financial institutions and their senior management. This is one of the examples of the 'ugly' faces of some of the bankers that are beyond the Shariah compliance. Hence, this study intends to compare the credit management's procedure in one of the full-fledged Islamic banks and one of the conventional banks which also offer Islamic banking window. This study also aims to analyse the achievement of maqasid al-Shariah through the procedures of credit management in the two respective banks.

\section{Methodology}

The interview method is the fundamental method for the primary data collection to get the detail and valid information concerning the procedure of credit management of the commercial banks. Commonly, interviews can be classified into three categories namely standardized interview (formal or structured), unstandardized interview (informal or nondirective) and semi standardized interview (semi structured or focused). This study has chosen to adopt the semi-standardized (guided, semi-structured or focused) method by having face to face interview as the key method of accumulating the data regarding NPF as well as credit management procedure (Alwi, 2012). During the data collection process which is gained from the interviews, a few questions related to the research area were emailed to the respondents in advance before the real interview session took place. Throughout the interview session, the question asked to the respondents is similar to the questions that had been emailed in advance. The respondents were entailed to answer the questions in detail in order to give a better understanding regarding this topic. Fascinatingly, the respondents managed to emerge with new questions pertaining to this research which can help in convoluted the management of credit for this study.

At the beginning, two of the full-fledged Islamic banks have been contacted during the study. However, only respondent from Bank B, which wishes to remain anonymous, has granted the permission to be interviewed. As for the conventional commercial bank, the researcher interviewed the Executive Director Country Head, Risk Management of Bank A, which also wishes to remain anonymous. The interviews were conducted fully in English language. For Bank B's interview which is conducted with the Senior Vice President of Credit Management Division, it was interjected with Malay language feedback and questioning as it is depends on the officer's comfort and convenience to answer whether in Malay language or English language. The period of interviews conducted is around one to two hours. All interviews were conducted once for each respondent while the audio being recorded and then transcribed fully.

The credit management of both Bank A and Bank B as well as the existence of elements of maqasid al-Shariah in the credit management process are discovered from the interviews conducted with the bank's officer and through some reading materials. The management processes include the initial steps of giving and approving the financing to the customer until the actions taken to the defaulting clients. These processes are also explained in detail from the early stage until the last resort. The data obtained is interpreted using the content analysis method. The reason of choosing this method is because this study used open ended questions for the interview. At first, the researcher listened a few times of the recorded interview before the data being transcribed into text form. The data is then arranged according to the question asked in order to study the similarities and differences between the respondent's answer (Htay and Zaharin, 2011).

The qualitative researches are open to criticism for being subjective and biased (Cavana, Delahaye and Sekaran, 2001). However, the interview question asked to the respondents has been checked and approved by Islamic banking expertise. Further, the interview question also had been emailed in advance. During the interview session, the respondents had highlighted that they had already read through the question before the interview was conducted. 


\section{Finding}

\section{a) Analysis on Comparison between Bank A (conventional bank) and Bank B (full-fledged Islamic bank) on Credit Management}

The comparison between Bank A's and Bank B's credit management can be concluded during the three levels namely approving the loans or financing, monitoring the account and recovery process for defaulting clients as shown in Table 1 below. The major difference can be found on the approval level while the other two levels are having minor different.

During the data analysis, the researcher found out that Bank A has a stricter credit approval procedure as compared to Bank B. This is because, instead of using the basic five C's of credit analysis which is also used by Bank B, Bank A has developed their own credit framework. Therefore, Bank A can ensure the loans that are granted to the customer have a low possibility and probability to default as the customers need to go through a series of strict credit approval procedure. The series of credit approval includes having a clear customer profile, clear credit guidelines, clear credit process, credit limit and target segment.

The first factor in five C's is the capacity to repay which is the most vital among the five factors. This factor refers to the primary source of repayment of the financing which is cash. Banks will want to know precisely how the customers plan to make their financing repayment. Normally, banks will consider the cash flow of the business, the timing of the repayment, and the probability of defaulting to happen in the repayment of the financing. The history of payment on existing credit relationships whether for personal or commercial purposes, is considered as an indicator for the future payment performance. Besides, bank also will want to discern about other possible sources of repayment that the customer might possess.

The second factor would be the capital; the money each customer personally has invested in the business as it would indicate how much the customer has at risk in the event of failure of the business. Bank will expect the customer to have contributed from their own assets and to have undertaken personal financial risk in order to establish the business before asking the customer to commit any funding.

Collateral, or guarantees, are another part of the five C's factor in credit analysis. Giving the bank collateral as the customers pledge their own asset, such as their house, with the condition that it will be on the reimbursement basis in case of the failure of customer to make the repayment. On the other hand, a guarantee means that someone else makes a promise to repay the financing if the customer fails to do so. In the banking industry practices, the bank may require such a guarantee in addition to collateral as a security measure towards financing that is given to the customers.

The fourth factor would be the conditions which portray the intended objective of the financing. The money may be used for working capital, for purchase of inventory or additional equipment. Bank will also consider about the economic conditions, in both local and the overall climate, within the customers' industry and in other industries that could influence their business.

The last factor is character, which is the general impression made on the prospective lender or investor. The lender will form a subjective opinion as to whether or not the customers are sufficiently trustworthy to repay the loan or generate a return on funds invested in their company. Their educational background and experience in business and in the industry will, therefore, be considered. The quality of their references and the background and experience levels of the employees will also be reviewed.

As for the second level which is the monitoring process, both of the banks are having a different management to conduct the monitoring process, instead of using the same approval team. Bank A is having an Account Relationship Manager (ARM) while Bank B is having the Centralized Call Centre (CCC) and Business Financing Supervision and Recovery (BFSR) units. Under ARM in Bank A, there will be a special report every certain day of the month, which will indicate the account's behaviour whether the customer is paying on time or whether the possibility of NPL will happen. Hence, in the event of expected default, the bank can contact the customer earlier to find a solution or alternative to avoid default problems. For Bank B, the bank will only monitor the account by giving a reminder or notify customers of the next payment due date. Therefore, there is no existence of a special report.

Under the recovery process which is the last level, there will be a different team that attends to the defaulting customers. For Bank A, it will be managed by a team called Special Asset Management, which is having the priority of trying to rehabilitate the defaulting client's account. However, if rehabilitation cannot be conducted, the bank needs to liquidate the company's or customer's asset. The rehabilitation is to be done during the shortest time period. 
For Bank B, the team responsible is called Monitoring Collection and Recovery Centre (MCRC) who will manage the delinquent accounts while BFSR managed the recovery process for Corporate and Commercial Financing.

Table 1. Comparison between Bank A and Bank B on credit management

\begin{tabular}{|c|c|c|}
\hline $\begin{array}{ll}\text { Process } & \text { Bank } \\
\end{array}$ & Bank A & Bank B \\
\hline Approval & $\begin{array}{l}\text { Has a stricter credit approval } \\
\text { including clear customer profile, } \\
\text { credit guidelines, credit process, } \\
\text { credit limit and target segment. }\end{array}$ & $\begin{array}{l}\text { Use five C's credit analysis } \\
\text { which are capacity, capital, } \\
\text { collateral, conditions and } \\
\text { character. }\end{array}$ \\
\hline Monitoring & $\begin{array}{l}\text { Involving a different management } \\
\text { than the credit approval, which is } \\
\text { Account Relationship Manager } \\
\text { (ARM) together with the Risk } \\
\text { management. Every certain day } \\
\text { of the month, there will be a } \\
\text { special report that will indicate } \\
\text { whether the customer is paying } \\
\text { on time or whether NPL will } \\
\text { happen. }\end{array}$ & $\begin{array}{l}\text { Involving a different management } \\
\text { than the credit approval, which } \\
\text { are called the Centralized Call } \\
\text { Centre (CCC) and Business } \\
\text { Financing Supervision and } \\
\text { Recovery (BFSR). }\end{array}$ \\
\hline Recovery & $\begin{array}{l}\text { Manage by Special Asset } \\
\text { Management, which will try to } \\
\text { rehabilitate the account. If cannot, } \\
\text { the bank will liquidate customer's } \\
\text { asset during the shortest time } \\
\text { period. }\end{array}$ & $\begin{array}{l}\text { Monitoring Collection and } \\
\text { Recovery Centre (MCRC) will } \\
\text { manage delinquent accounts } \\
\text { while BFSR manage the recovery } \\
\text { process for Corporate and } \\
\text { Commercial Financing. }\end{array}$ \\
\hline
\end{tabular}

\section{b) Analysis on the Achievement of Maqasid Al-Shariah in Bank A's and Bank B's through the procedures of Credit Management}

The analysis on achievement of maqasid al-Shariah in Bank A's and Bank B's through the procedures of credit management is focused during the three levels namely approving the loans or financing, monitoring the account and recovery process.

It can be analysed from the stringent clear profiling adopted by Bank A that it ensures that only the customers with the capability in paying back the loan or financing will be given the approval. On the other hand, it safeguards the maslahah (benefit) of having too much defaulting clients and at the same time lessening the number of NPLs. Hence, the serious sequence of bankruptcy and insolvency can be avoided. It is aligned with one of the purposes and goals of Shariah, which is the protection of wealth.

When Bank B are less strict in approving customer with financing, maqasid al-Shariah also can be achieved in terms of customer can secure an asset through the financing or they can enhance the business that they intend to invest using this financing. Hence, the standard of living can be improved and at the same time maintained the wealth accumulation. Maqasid al-Shariah is achieved through the protection of human life and wealth with regards to the enhancement of quality of living among customers.

The approval process that has been practiced by both Bank A and Bank B is quite contradictory in a way that one of the banks is way stricter while another is less strict. When there is a conflict between two situations, the purpose as well as the effect behind the practices need to be analysed. This is done to find out which practices will give more benefit while preventing harm to the society. It is because maqasid al-Shariah itself is aiming on the achievement of good, welfare, benefits (masalih al-'ibad) and at the same time to protect against events of injury and loss. In this case, the stricter approval by Bank A should be prioritised than the lesser one that is practiced by Bank B. It is because by having a strict approval, it can reduce the cases of non-performing loans hence safeguarding them from 
bankruptcy and insolvency. Although the act of lending the money to those in need is highly encouraged from an Islamic viewpoint, the after effects that could lead to serious harm should be prevented.

Despite the fact that the less strict approval can give benefits to the customers, the consequence of bankruptcy and insolvency are way more damaging. Therefore, harm and loss should be avoided primarily before aiming to achieve benefit and welfare. However, Bank B alternative to reduce non-performing financing can be seen from the existence of two units under monitoring and recovery stages.

During the monitoring process, Bank A will get a special report from its ARM which will indicate the account behaviour. Hence, an early warning in case the customer is going to have a problem to comply with the schedule of monthly instalment can be detected. The banks sometimes gave permission to those special cases by not having to pay for certain month if the customers are undergoing some serious problems. Therefore, the customer will not be burdened by their debt during their hard times. Therefore, the welfare of society can be maintained thus achieving maqasid al-Shariah. For Bank B, the bank will only monitor the account by giving a reminder or notify customers of the next payment due date. Therefore, there is no existence of a special report.

Apart from that, during the recovery process in Bank A, when the customer reached certain limit of default, the bank then will enter into an agreement with the customer for restructuring or rescheduling of their previous financing. It can be concluded that bank is trying to help the customer by granting rescheduling facility, which help to extend the period of loans and financing in order to decrease the amount of monthly instalment. This practice is coincided with what Islam recommends the lender to be lenient towards the debtor that are facing difficulty to make debt settlement in order to avoid from bankruptcy happened. For Bank B, the respective team, MCRC will manage the delinquent accounts while BFSR managed the recovery process for corporate and commercial financing.

The existence of conventional banking until this day is based on profit orientation. During the establishment of Islamic bank as an alternative to the conventional, the products and services offered are just a shadow as what the conventional are offering. Nevertheless, it is based on the principles of Shariah. When the westerners came out with corporate initiatives known as Corporate Social Responsibility (CSR), which is welfare given to the society, Islamic banks are also implementing this kind of initiative. However, value based is different from CSR as it is deemed more than just welfare.

The issuance of Value Based Intermediation (VBI) Strategy Paper urges Islamic banking to adopt value-based intermediation as a common vision for the banking industry. The functions of VBI is to deliver the intended outcomes of Shariah and minimisation of negative impact arising through banking practices, offering and conduct, in order to generate sustainable impact to the economy. The intended outcomes of Shariah focus on the enhancement of well-being of the society through the protection of wealth, faith, lives, intellect and lineage. In the context of Islamic financial practices, the protection of wealth is beyond than its literal meaning as it motivates to generates, accumulate as well as distribute the wealth in a fair and just way.

By having a strict credit approval practiced by Bank A, it can help to protect the wealth. This is due to the reason that only customer that has the capability and capacity to pay back can make a loan. Thus, can avoid the incapable customer from having non-performing loan, hence safeguards them from bankruptcy and insolvency. However, by having less strict credit approval practiced by Bank B, the wealth accumulation can be achieved. From the Islamic perspective on the context of fard kifayah (social obligation), those who are capable is responsible to assist those who are not capable through the effective distribution of wealth. Hence, in the banking industry, banks play a significant role for the society in creating socioeconomic impact.

Bank A also upholds the principle that banks are not only lending money, but also to bring prosperity for the customers by granting them loans at a reasonable price which can benefit both parties. Hence, the successful distribution of wealth can be maintained.

\section{A Way Forward}

There are a few recommendations proposed to future researcher, industry and policy maker. It is suggested to the future researcher to carry out a more detailed research regarding this topic. An analysis of comparison on a more numbers of commercial banks can be conducted in order to have a broader idea of credit management. To make it better, selected banks with a higher percentage of NPL as well as those banks with a lower NPL data should be included.

There are also some recommendations that may be considered by Islamic banks. The first is regarding the procedure of credit management. It is suggested that for a better quality of financing granted to the customer, the approval process needs to be stricter. Therefore, it can be achieved by having a new framework for credit approval. Among 
the recommendations would be a clear credit approval such as the officer must be an expertise in industry that the customer aims to invest. Hence, the bank can understand the trend and need of the market that customer intends to involve on whether it is meet the logical sense in terms of having the capacity to handle it and having the right market.

Besides that, in the event of default and the customer ask for rescheduling, the bank should consider to make it an obligation for the customer to take takaful protection against financing. It is purposely to avoid further default problems which clearly will burden them. As the bank already understands the customer's capability in paying the monthly instalments in the event of default, there would not be a guarantee that after the rescheduling, the customer can afford to make monthly instalments without failing to do so as in schedule.

Policy makers should consider the setting up of an efficient and effective credit management guideline which includes the steps from the early stages of approval until the last resort of recovery in the event of default. The guideline should consider both benefit of the banks and the customer in order to protect the benefit and welfare of the people in this life and in the hereafter, at the same time, preventing and avoiding harm from occurring.

\section{Conclusion}

As a conclusion, this study is considered as a new area of research as there are limited number from the past research that was done with regard to credit management and maqasid al-Shariah. Non-performing loan give bad affect to both conventional and Islamic bank. However, from the Islamic perspective, it is less favourable as it is conflicting with what Islam has upheld in one of its goals, with regards to protection of the five essential elements especially in respect to the protection of wealth.

Results indicated that both of the banks have their own strategy to safeguard from non-performing loan happening. However, Bank A is having a stricter credit approval process compared to Bank B. Nevertheless, there are a lot of aspects that need to be looked into before the loan and financing can be approved to be given to the customers. The analysis of the comparison between a conventional and Islamic bank is generated from the approval, monitoring and recovery stage. Eventually, the strict approval practiced by Bank A should be prioritised instead of the less strict version practiced by Bank B. It is because by using a strict approval, it can reduce the cases of non-performing loans hence safeguarding customers from bankruptcy and insolvency.

Although the practices of lending the money to those in need is highly encouraged from the Islamic perspective, the aftereffects that could lead to harm such as bankruptcy should be considered in order to prevent it from happen. As in this situation, the harm of bankruptcy is weighted to be more damaging than its benefit, wealth accumulation. Apart from that, the attainment of maqasid al-Shariah and the existence of value-based intermediation in both bank's credit managements can also be founded on.

Therefore, in order to apply value based in any particular organization, it may start from the individual level. In the banking industry, bank officers should try their best in assisting customer by giving honest advice according to the customer's actual necessity and capability. Thus, the infidelity of profit intensification can be avoided hence wastage will vanish.

\section{Acknowledgement}

We wish to thank the Research management Centre of Universiti Teknologi MARA and Institute of Graduate Studies of Universiti Teknologi MARA for their support and funding.

\section{References}

Abadi, A. F. (2008). Al-Qamus Al-Muhit. Beirut: Dar Al-Fikr.

Abdullah, N. S. N., \& Abd Wahab, N. (2015). Investigating Factors Affecting the Intention to Use Islamic Personal Financing. International Journal of Management Studies, 22, 47-60.

Abozaid, A., \& Dusuki, A. W. (2007, April). The Challenges of Realizing Maqasid Al-Shariah in Islamic Banking and Finance. In Proceding Paper presented at IIUM International Conference on Islamic Banking and Finance, IIUM Institute of Islamic Banking and Finance (pp. 23-25).

Al-Fasi, A. (1993). Maqasid Al-Shariah. Beirut: Dar Al-Gharb Al-Islami.

Al-Shatibi, A. I. (1997). Al-Muwafaqat. Lebanon: Dar Al-Ma'rifah.

Alwi, S. F. S. (2012). Shari'ah and Regulatory Issues of Islamic Trade Finance in Malaysia (Unpublished doctoral dissertation). Institute of Islamic Banking and Finance, International Islamic University Malaysia, Gombak, Selangor. 
Ashur, M. A. T. I. (2006). Maqasid Al-Shariah Al-Islamiyyah. Kuala Lumpur: Islamic Book Trust.

Bakar, M. D. (2016). An Insightful Journey into Emirates Airline Sukuk, Pushing the Boundaries of Islamic Finance. Kuala lumpur: Amanie Media Sdn Bhd.

Bank Negara Malaysia. (2017). Value-based Intermediation: Strengthening the Roles and Impact of Islamic Finance. Bank Negara Malaysia. Retrieved October $28, \quad$ 2017, from https://www.bnm.gov.my/index.php?ch=57\&pg=137\&ac=612\&bb=file

Cavana, R. Y., Delahaye, B. L., \& Sekaran, U. (2001). Applied business research: Qualitative and quantitative methods. John Wiley and Sons Australia.

Chapra, M. U. (2000). Why has Islam Prohibited Interest: Rationale behind the Prohibition of Interest. Review of Islamic Economics, 9, 5-20.

Chapra, M. U. (2016). The future of economics: An Islamic perspective (Vol. 21). Kube Publishing Ltd.

Dimitrios, A., Helen, L., \& Mike, T. (2016). Determinants of non-performing loans: Evidence from Euro-area countries. Finance Research Letters, 18, 116-119.

Dusuki, A. W. (2009). Challenges of Realizing Maqasid Al-shari'ah (objectives of Shari'ah) in the Islamic Capital Market: Special Focus on Equaty-based Sukuk Structures. International Shari'ah Research Acedemy for Islamic Finance (ISRA).

Dusuki, A. W., \& Abozaid, A. (2007). A critical appraisal on the challenges of realizing Maqasid Al-Shariaah in Islamic banking and finance. International Journal of Economics, Management and Accounting, 15(2), 143-165.

Haron, S. (1995). The Philosophy and Objective of Islamic Banking: Revisited. New Horizon, 46/47, 5-7.

Hou, Y., \& Dickinson, D. (2007). The non-performing loans: some bank-level evidences. In 4th International Conference on Applied Financial Economics, Samos Island, Greece.

Htay, S. N. N., \& Zaharin, H. R. (2011). Critical analysis on the choice of Takaful (Islamic Insurance) operating models in Malaysia. European Journal of Business and Management, 6(15), 2014.

Kamali, M. H., \& Yussof, S. A. (2013). Islamic Transaction and Finance, Principles and Developments. Selangor: The Malaysian Current Law Journal Sdn Bhd and Kuala Lumpur: International Institute of Advance Islamic Studies.

Karim, M. Z. A., Chan, S. G., \& Hassan, S. (2010). Bank efficiency and non-performing loans: Evidence from Malaysia and Singapore. Prague Economic Papers, 2(2010), 118-132.

Lahsasna, A. (2013). Maqasid Al-Shariah in Islamic Finance. Kuala Lumpur: IBFIM.

Malaysian Business. (2013). Islamic Banking: How It All Began, pp. 60-61.

Setiawan, C. H. A. N. D. R. A. (2012). Non-performing Loans and Bank Efficiency of Conventional and Islamic Banks in OIC Countries. Selangor: Universiti Putra Malaysia.

Sufian, F., \& Kamarudin, F. (2016). Determinants of efficiency in the malaysian banking sector: Does bank origins matter?. Intellectual Economics, 10(1), 38-54.

The World Bank. (2016, October 13). World Bank Group. Retrieved from https://data.worldbank.org/ 